\title{
THE TREATMENT OF DEEP CANDIDIASIS OF THE MOUTH AND PHARYNX THE CONBINED THERAPY WITH TRICHROM- YAIN AND ION CARBONHYDRATE DIET
}

\author{
$\mathrm{By}$ \\ Y. KOBAYASHI \\ Department of Oto-Rhino-Laryngology, Nagasaki University, School \\ of Medicine, (Director: Prof. T. Goto) \\ and T. MATSUMOTO \\ Department of internal medicine, Nagasaki University, School of Medicine, \\ (Direcor: Prof. M. Yokota)
}

The deep candidiasis of the mouth and pharynx has been rare disease and the satisfactory treatment has not yet been established. The authors have examined the blood sugar level on 7 patients who had chronic ulcer due to candida infeetion. They found that the blood sugar level of these patients was generally high and particularly its decline after giving the Sakaguchi's test diet was prolonged. In many cases the rate of the Staub's effect at 120 minutes was higher than at that of 60 minutes.

Based upon these findings, the authors devised the satisfactory treatment consisted with trichomycin (Hosoya) and ion carbonhydrate diet.

\section{口腔 咽 頭 Candida 症 $の$ 治療法 \\ （トリコマイシン含水炭素制限食併用療法）}

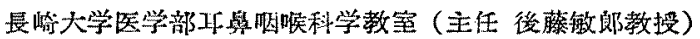

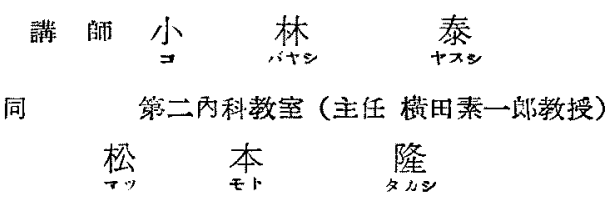

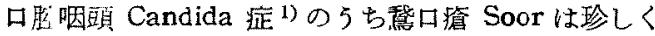
ないが䟺瘁を作る梁性の C 症は稀有な疾患と見做され， 治療治、としては古くからのョードカリの内服をはじぬ種 タなオ法が試みられているが，奏際には礁䒠な治療法が

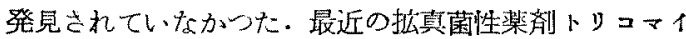
シン3の器見によつて本症の治療にはや」希望が持てる よ5になつたが未だ根治を期するには困難な状態であ る.我ふは前にインシニリン注射による治療法2 を発表 したが，その後症例の增加に伴つてこの方法の検討をす メめ.トリコマイシンと共に C 症患者の 糖代謝障碍治 療を佃对することによつて非常によい結果が得られるよ
らになつたので報告する・

I） C症の糖代謝障碍とその治療

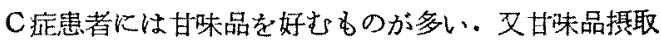
後あるいは館食後に自賞症状の悪比するのつおること はわれわれの経驗するところである・双難治であつた㸶

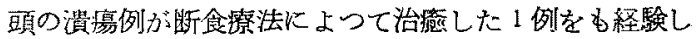
た・このよ 5 な点からC症患者の糖代謝には何か暴常が. あるのではないかと想像し，われわれは先ゔ船䜻の変 化に就て検討した。

C症の誩断の確定した㭧者 5 名, 䛦断磪定に至らなか つたが C 症の疑いの患者 2 名に就て坂口試嗝と Staub 


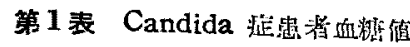

\begin{tabular}{|c|c|c|c|c|c|c|c|c|}
\hline 8 & 疾患 & 原 & 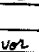 & $\frac{13}{30^{\circ}}$ & & 武 & 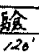 & 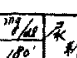 \\
\hline 山本 & ○焢C症 & 33 & 80 & 220 & & & 94 & 94 \\
\hline 湹 & & $\% / \pi$ & 18 & 96 & & 184 & & $228 \%$ \\
\hline 村 & (n) & $20 / 1 x$ & 95 & 41 & & 45 & 104 & $\Rightarrow$ \\
\hline A上 & " & $7 / 7$ & 1 & 48 & & & & 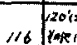 \\
\hline 川尾 & & 74 & 78 & 102 & 121 & 87 & 18 & - \\
\hline 小: & {$[0$} & $2 \%$ & 97 & 111 & 34 & os & 104 & 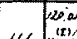 \\
\hline 畩田 & 上 & \% & 94 &, 74 & 165 & S1 & 124 & " \\
\hline Fnst & & & 91 & 121 & 158 & 145 & 133 & 12 \\
\hline 绪 & $128 \bar{F} \times 9$ & & 8 & & & & 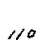 & 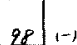 \\
\hline
\end{tabular}

第 2 表 Candida 症患潜血糖値

\begin{tabular}{|c|c|c|c|c|c|c|c|c|c|c|}
\hline 患名。 & 疾患 & ${ }^{2}$ & & $\frac{t a}{30}$ & & $\mathrm{PO}^{\prime}$ & & & $80^{\circ}$ & 泉, \\
\hline 山本 & 口悾C在 & $16 / 0$ & 24 & 132 & 102 & 74 & 121 & 105 & 88 & $(-1$ \\
\hline 北原 &. & 6 & 72 & 125 & 128 & 102 & 119 & 134 & 95 & $1-1$ \\
\hline 山村 & (治意柽怪) & $4 / x$ & 99 & 150 & 14 & 22 & 1,24 & $(x)$ & $2 x$ & $1-1$ \\
\hline 井上 &. & 20 & 101 & $\pi 8$ & 197 & 148 & 189 & $\delta_{c}$ & 1.39 & $1-1$ \\
\hline$\pi$ 尾 & 2 & $2 \%$ & 99 & (III) & 115 & 97 & 145 & 196 & 104 & $(-1)$ \\
\hline 小沈 & 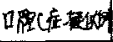 & 2 㽜 & 96 & $3 s$ & $|s|$ & 114 & 139 & 142 & 80 & -1 \\
\hline 里田 & 企 $=$ & $2 \frac{23}{8}$ & 89 & 121 & 168 & 155 & 141 & 14 & 182 & $1-1$ \\
\hline 平坊值 & & & 90 & 139 & 144 & 130 & 147 & 137 & 109 & \\
\hline 传布 & 126759 & & 94 & 128 & 120 & $\mu z$ & 102 & & .99 & $(-1)$ \\
\hline
\end{tabular}

効果を検查した。その成續は次表に示すようである。 (第 1,2表)

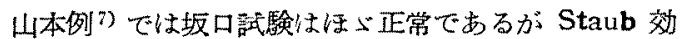
果に执いて120 分值が高く，川原例では両試験とも高血 糖值が永く持続している.山村例5) では坂口試験は血糖 值の低下が执くれ，Staub 効果は120 分值が 高い値を

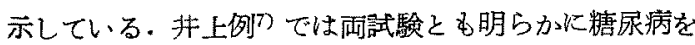
思わせる成績であつた，竹尾例》る亦 120 分值以後の血 結值が高く且つ持続時間が長い，又 Staub 好果では 120 分值が 60 分值より高い,值を示している.小池例, 野 田例でるや>同样な傾向が認められた。

以上の上弓な成績を対职の煡者 12 名の平均值 と比較 すると次表の如くでる。(第 3，4表)

患者群比糖疗病患者を有するため両者の曲線には相当 な大きい差を生じたが，たとえこれ等の例を除外してる 路者曲線との間にはな和相当な広い開きがあることがわ かる。即ちC症患者は一般に 120 分值以後の血楉值の下 降が遅れ，120 分值，180 分值に打いて子な括 $100 \mathrm{mg}$ 以 上の高刞糖を持続する傾问があり, Staub 効果では 120
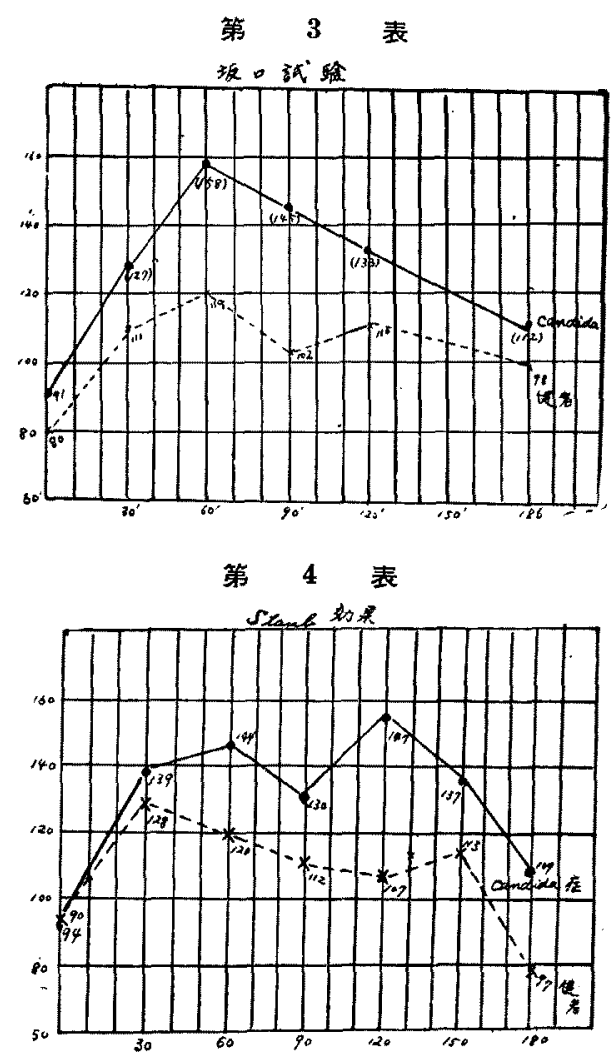

分值が 30 分值より高くなる傾向におる、これをるつて 糖尿病と断ずるわけではないが糖代謝に異常のあること が見られる.このような糖の代謝障碍は Candıda の粘 膜感染の一つの要因と考光られたので次の上うな治療法 を行つた。

(1) インショリン注射, (2) メゾキサン鋔内服, (3) 含 水炭素制限食饂療法.

インシニリン注射にはレギュラーインシュリンあるい はプロタミンチンクインシニリン, NPH インシュリン 等を食前 30 分に5 10 単位注射した・メゾキサン鎵仗

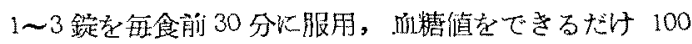

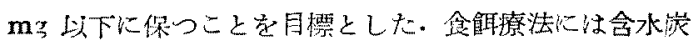
素 $200 \mathrm{~g}$ ，蛋白質 $100 \mathrm{~g}$ ，脂肪 $50 \sim 60 \mathrm{~g}$ ，Cal. 2600 を基集 にした食䬦を与えることにした・いずれの力法も2 週間 以上は続ける必要がある.われわれの教室での冶療経殹 を示寸と次表の如くでちる.（第 5 表）

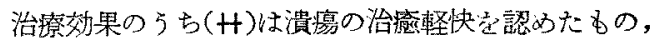
(十)は皟瘍の治癒は著明でないが自敩的に症状の軽快を 訴えたものである・表によるといずれの例汇㧊いても共 


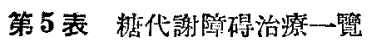

\begin{tabular}{|c|c|c|c|c|c|c|c|c|c|}
\hline$a \&$ & 57 & 相 & 解 & & 治 & 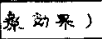 & & & \\
\hline 4 & 20 & है। & 口䏠 & インiZyン注 & + & Ay & - & 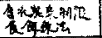 & $\forall$ \\
\hline “) 乘 & 44 & t & 12 䏠 & 1>i2y, i住 & 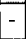 & $x y+y=$ & 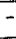 & & $t$ \\
\hline 4 上 & 61 & $f$ & 12 曹 & $1 \times 5 x y>3 z$ & $\pi$ & $x y+7+1-2$ & r & & \\
\hline 山材 & 27 & $t$ & 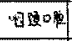 & 1)议9>注 & it & 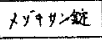 & & & \\
\hline$\pi R$ & 43 & 9 & $\therefore$ 难 & 理 & - & $x y+y=$ 位 & & & ? \\
\hline 小池 & 54 & s. & $\therefore$ 倌 & & & AYA1 知 & & & $?$ \\
\hline 九1 & 24 & 9 & 古 & & & 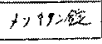 & & 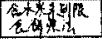 & 4 \\
\hline
\end{tabular}

通して有効であつたのは食䬺潦法である・インシニリン は症例飞上つて有效であり，川原例，竹尾例の如く而糖 值は高いのに拘らず無效な例もある・メゾキサン錟の内 服は山本，川源，竹尾，小池例では無効であつたが，内 服薬であるから患者の自宅療法が可能な点に执いて一応 試みてよい薬物である.川原例ではインシニリン注射が 無效で食䭒療法が有效ですつた点は単なる四糖值のみの

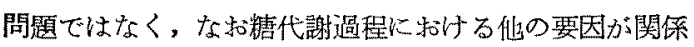
するものと洘えられる。

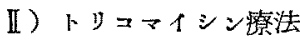

トリコマイシンタ抗真菌製薬㶡のうちでは現在最も傮 れたすのであることは広く一般に認められている。この 抗菌作用に就てわれわれは既に日耳鼾会報4)に報告した ので省略した，次表はその臨林効果である，(第6表)

第 6 表 トリコマイシンの治礉效果

\begin{tabular}{|c|c|c|c|c|c|c|c|}
\hline 氏石 & $4 \hat{\gamma}$ & 妵 & 部 住 & 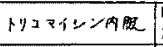 & 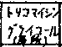 & & 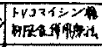 \\
\hline 山村 & 29 & 5 & $a^{2}$ & $H+(15.000 \times 501)$ & $\pi$ & & $\pi$ \\
\hline 5 波 & 47 & 9 & $\square 1$ & $-(60000 \times 87)$ & \pm & & 6 \\
\hline$\omega \neq$ & 20 & 5 & 数韵 & $+(45000 \times 307)$ & + & + & + \\
\hline 41 & 61 & $t$ & 整急 & $\#(60.000 \times 607)$ & $\pi$ & & 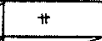 \\
\hline 永江 & $m$ & 5 & Fis & $\pm(60.000 \times 501)$ & \pm & & \\
\hline “原 & 44 & 5 & 哣 & $+(60.000 \times 50 T)$ & $t$ & + & + \\
\hline 大埰 & 24 & 9 & 舌 & $+(60,000 \times 201)$ & + & 7 & $\#$ \\
\hline
\end{tabular}

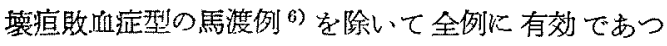
た・トリコマイシンの久点は効果が次第に減弱すること

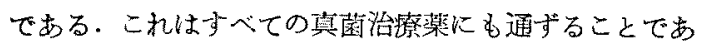
るが，これが酎性獲得によるものかど5が就てはわれ

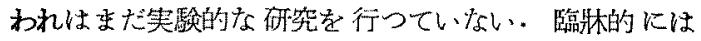
3〜4 週後には效果が減弱するようである。

局所的にわれわれはトリコマイシン $5000 〜 10,000$ 単位 をブロピレングライコール1cck溶解したものを1日 数回口腔内に整布している.内服と伤用し，むるいは篹

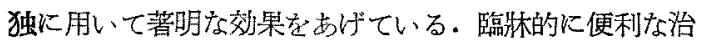
潦法でする。
最近米国 Squibb 社の Mycostatin, Mcyosteclin 輸入さたたので試用した・2，3の経験例ではこれる又有

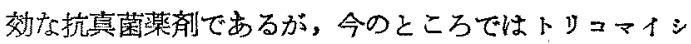
ンより嚤えているとは思京ない結果を得ている。

含濑洞としては1\%過マンガン酸液，0.02\%モチフラ シン液, 0.02\% マーゾニン水等が用いられているが，效

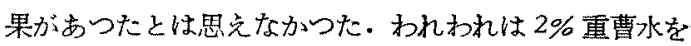

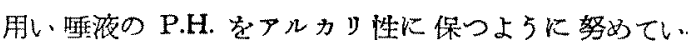
万.

III）トリコマイシンと含水炭素制限食併用寮法 前述した I，IIの方法はいずれる有效であるのでか～ れわれは更にI，IIの方法を同特に行つた。その結果は 第6表に示す如くである.山村例はィンシュリン虔法， トリコマイシン内服により沿拴退院したが，その後約半 年して再び軟口蓋に小溃昜を生じたので含水㞸素制限食 飭潦法とトリコマイシンの内服 15 日間 90 万篻位とその 座所湮布 4 ケ月によつで完治した。川原例はトリンマイ シンの笚独使用では左程効果は見られなかつたが, 食餌 癖法との併用により效果が得られた。井上例，大坪例は

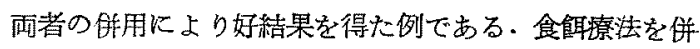
用することによりりリコマイシンの效果は更に強められ. ることがわからた。

\section{結語}

口腔, 咽頭粘膜の㳭性のカンヂダ症 (deep Candidiasis）の樍代謝に就ての小觬察を述べ，治潦にはトリ マイシンと含水宥素制限食䬣療法との併用が最も有好で あること老報告した。

\section{主 要 文 献}

1)後藤：カンデイダ成，医学の進步，99,1956. 2) 後藤・小林：明頭及び口腔の粘膜のモニリア性溃瘍と インシンリン祭法，踟鼎と哳究，31；664，1954.

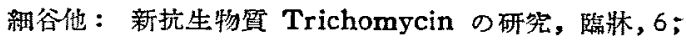

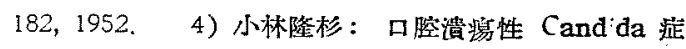

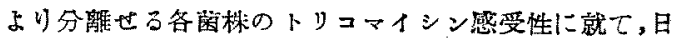

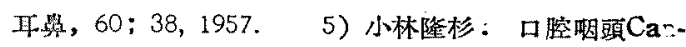

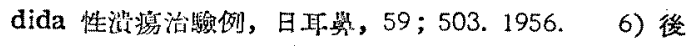

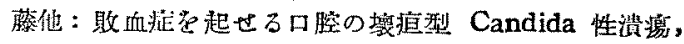

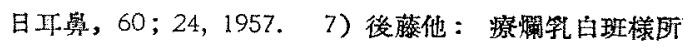

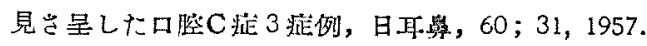

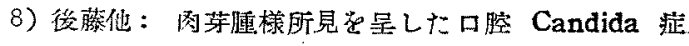
例, 日平學, 60；28, 1957.

\footnotetext{
（原稿到籍＝昭 32.2.16日）
} 